\title{
DOS ATOS DE CONSTRIÇÃO ANTES DE AJUIZADA AÇÃO EXECUTIVA: UM ENFOQUE SOBRE O APROVISIONAMENTO DE CRÉDITO DE CONTA BANCÁRIA DE CORRENTISTA PELOS BANCOS
}

JOSÉ EUSTÁQUIO DE MELO JÚNIOR 


\section{DOS ATOS DE CONSTRIÇÃO ANTES DE AJUIZADA AÇÃO EXECUTIVA: UM ENFOQUE SOBRE O APROVISIONAMENTO DE CRÉDITO DE CONTA BANCÁRIA DE CORRENTISTA PELOS BANCOS}

José Eustáquio de Melo Júnior ${ }^{1}$

\section{RESUMO}

O presente trabalho tem por objetivo analisar a licitude da conduta de algumas instituições bancárias no Brasil que promovem o chamado "aprovisionamento de crédito" na conta bancária de seu correntista, sem que exista ação executiva ajuizada em seu desfavor, para viabilizar o adimplemento de débito autorizado pelo próprio titular da conta bancária em contrato firmado com o banco. Nessa perspectiva, buscase delimitar a natureza jurídica da relação negocial travada entre o banco e o correntista e se disso decorre a possibilidade de aplicação do Código de Defesa do Consumidor, abordando-se em seguida alguns aspectos constitucionais, legais e principiológicos sobre essa conduta de aprovisionamento de crédito pelo banco, para, finalmente, chegarse a uma resposta quanto à legalidade, ou não, dessa conduta. Foi desenvolvido com base em pesquisa bibliográfica, situando-se o tema na área de Direito Processual Civil.

Palavras-chave: Atos de constrição. Aprovisionamento de crédito. Conta bancária. Ação executiva. Direito Processual Civil.

\section{RESUMEN}

El presente trabajo tiene por obejectivo analizar la licutad de la conducta

$1 \quad$ Juiz de Direito do Poder Judiciário do Estado do Tocantins, Titular da Comarca de Xambioá-TO. Graduado em Direito pelo Uniceub. Pós-graduado em Ciências Jurídicas pela Universidade Cândido Mendes. Pós-graduado em Gestão do Poder Judiciário pela FAEL. Mestrando em Ciências Jurídicas pela Faculdade de Direito da Universidade de Lisboa em parceria com a Escola Superior da Magistratura de Pernambuco (ESMAPE). E-mail: eustaquio@tjto.jus.br 
de las algunas instituciones bancarias en Brasil que promueven el llamado "aprovisionamiento de crédito" en la cuenta bancaria de su cuentacorrentista, sin que exista acción ejecutiva ajuizada en su disfavor, para hacer viable el cumplimiento de lo débito autorizado por el propio titular de la cuenta bancaria en contrato firmado con el banco. En perspectiva, buscase demilitar la naturaleza jurídica de la relación negocial firmado entre el banco y el cuentacorrentista y si derivar en la posibilidad de aplicación del Código de Defensa del Consumidor, abordando-se enseguida algunos aspectos constituciolales, legales y principilógicas sobre esa conducta de aprovisionamiento de crédito por el banco, para, finalmente, aproximarse a una respuesta cuanto a la legalidad o no de esa conducta. Fue desarrollado con base en investigación bibliográfica, situandose eltema en la área de Derecho Procesal Civil.

Palabras-clave: Acto de constricción. Aprovisionamiento de crédito. Cuenta bancaria. Acción ejecutiva. Derecho Procesal Civil.

\section{INTRODUÇÃO}

Nos últimos anos no Brasil, tem-se observado a adoção de uma prática comum, por algumas instituições bancárias, classificada como "aprovisionamento de crédito" na conta bancária de seu correntista, sem que exista ação executiva ajuizada em seu desfavor, para viabilizar o adimplemento de débito autorizado pelo próprio titular da conta bancária em contrato anteriormente firmado com o banco.

Cuida-se, a nosso ver, de situação relevante e preocupante em face da possibilidade de violação de princípios constitucionais, normas legais e princípios ligados à ação executiva, como, por exemplo, o princípio do devido processo legal e da dignidade da 
pessoa humana, somente para antecipar alguns e que, por isso, necessitam do estudo aprofundado do intérprete.

Além disso, o tema desperta a necessidade de reflexão, especialmente em face da discussão em torno do aumento do nível de endividamento do consumidor brasileiro, e se encontra pouco explorado na doutrina, existindo alguns poucos precedentes jurisprudenciais em Tribunais brasileiros tratando especificamente da matéria.

Dessa forma, a delimitação do assunto proposto pauta-se na discussão em torno da licitude dessa prática pelas instituições financeiras, a fim de restringir a natureza jurídica da relação negocial travada entre o banco e o correntista e se disso decorre a possibilidade de aplicação do Código de Defesa do Consumidor, abordando-se em seguida alguns aspectos constitucionais, legais e principiológicos sobre essa conduta de aprovisionamento de crédito pelo banco, para, finalmente, tentar-se chegar a uma resposta quanto à legalidade, ou não, dessa conduta.

\section{APROVISIONAMENTO DE CRÉDITO EM CONTA BANCÁRIA DE CORRENTISTA DEVEDOR PELO BANCO}

\subsection{Breves considerações}

Normalmente, ao abrir a conta bancária no banco, o cidadão brasileiro tem à sua disposição alguns produtos e serviços oferecidos no contrato como, por exemplo, empréstimo CDC (Crédito Direto ao Consumidor), limite de cheque especial, títulos de capitalização, previdência privada, seguros e cartão 
de crédito. Além disso, encontra-se estipulado no contrato firmado pelas partes que dessa contratação implicará o dever de o consumidor pagar ao banco regularmente algumas tarifas para manutenção dessa conta bancária que fora aberta.

Nesse contexto, ao contratante é apresentado à assinatura um documento impresso previamente que caracteriza inegavelmente um contrato por adesão ${ }^{2}$, tendo em vista que a ele não é dada a possibilidade de propor, alterar ou impugnar qualquer de suas cláusulas.

Esse negócio jurídico, via de regra, é assinado pelas partes e por duas testemunhas, o que caracteriza a constituição de um título executivo extrajudicial, a teor do disposto no art. 585, inciso II, do Código de Processo $\mathrm{Civil}^{3}$, e poderia ensejar, caso desejasse o credor e presentes os requisitos legais, o ajuizamento de ação de execução por quantia certa contra devedor solvente.

No ajuste entabulado pelas partes, encontra-se normalmente cláusula prevendo a autorização do correntista ${ }^{4}$ para que o banco faça o débito automático de certos produtos e serviços contratados pelas partes, como as tarifas cobradas pelo banco, a parcela do CDC ou a fatura do cartão de crédito, por exemplo.

Portanto, o aprovisionamento de crédito da conta bancária

2 O Código de Defesa do Consumidor estabelece em seu art. 54: Contrato de adesão é aquele cujas cláusulas tenham sido aprovadas pela autoridade competente ou estabelecidas unilateralmente pelo fornecedor de produtos ou serviços, sem que o consumidor possa discutir ou modificar substancialmente seu conteúdo.

3 Art. 585 - São títulos executivos extrajudiciais: I - a letra de câmbio, a nota promissória, a duplicata, a debênture e o cheque; II - a escritura pública ou outro documento público assinado pelo devedor; o documento particular assinado pelo devedor e por duas testemunhas; o instrumento de transação referendado pelo Ministério Público, pela Defensoria Pública ou pelos advogados dos transatores.

4 Leia-se: correntista que não explora atividade econômica. 
consiste na operação pela qual o banco bloqueia a utilização de crédito correspondente a uma dívida (futura ou vencida) de modo que ao correntista é cerceado o direito de dispor daquele valor depositado em sua conta, restando-lhe liberada, somente, a diferença verificada.

\subsection{Contratos bancários e aplicação do Código de Defesa do Consumidor}

Com efeito, a relação que se estabelece normalmente entre o correntista e o banco por ocasião da abertura de conta bancária e, normalmente, à adesão a alguns produtos previstos no próprio negócio jurídico entabulado, como empréstimos CDC, cheque especial e cartão de crédito, inegavelmente caracteriza relação de consumo.

Essa tese se justifica posto correntista e banco se enquadrarem com perfeição nas definições de consumidor e fornecedor, respectivamente, descritas nos arts. $2^{\circ}$ e $3^{\circ}$ do Código de Defesa de Consumidor ${ }^{5}$. Ademais, o disposto no art. $3^{\circ}$, $\S 2^{\circ}$, do CDC indica com clareza meridiana que se enquadram na definição de serviço as atividades de "natureza bancária, financeira e de crédito".

Grinover (2001) distingue a existência de duas correntes principais que procuram explicar o art. $2^{\circ}$ do Código de Defesa do Consumidor: a finalista e a maximalista. Pela primeira, consumidor é a parte vulnerável nas relações contratuais de mercado, aquela pessoa que adquire o produto ou serviço em

$5 \quad$ Art. $2^{\circ}$ Consumidor é toda pessoa física ou jurídica que adquire ou utiliza produto ou serviço como destinatário final. 
proveito próprio, e não para utilização na cadeia produtiva de negócio que explore. Para os maximalistas, o Código de Defesa do Consumidor é o novo regulamento do mercado de consumo brasileiro e concebem o seu art. $2^{\circ}$ de modo mais extensível possível, de forma meramente objetiva, sem se importarem se a pessoa tem ou não fim lucrativo quando contrata, ou seja, consumidor é o destinatário fático do produto ou serviço, aquele que retira o produto do mercado e o utiliza.

Marques (2006), ao tratar do tema, lembra que os finalistas procuram interpretar o art. $2^{\circ}$ do Código de Defesa do Consumidor segundo o fim da norma que é a tutela do mais fraco na relação de consumo e cita o finalismo como uma tendência atual na jurisprudência dos Tribunais Brasileiros, especialmente no âmbito do Superior Tribunal de Justiça.

O Supremo Tribunal Federal, por ocasião do julgamento da ADI n ${ }^{\circ}$ 2591-DF, Relator Ministro Carlos Veloso ${ }^{6}$, concluiu em boa hora que as instituições financeiras estão, todas elas, alcançadas pela incidência das normas veiculadas pelo Código de Defesa do Consumidor.

Na mesma direção seguiu o Superior Tribunal de Justiça, que editou o enunciado ${ }^{\circ} 297$ de sua súmula, segundo o qual o Código de Defesa do Consumidor é aplicável às instituições financeiras.

Portanto, no contexto em estudo, a relação jurídica

Art. $3^{\circ}$ Fornecedor é toda pessoa física ou jurídica, pública ou privada, nacional ou estrangeira, bem como os entes despersonalizados, que desenvolvem atividade de produção, montagem, criação, construção, transformação, importação, exportação, distribuição ou comercialização de produtos ou prestação de serviços.

6 ADI 2591, Relator(a): Min. CARLOS VELLOSO, Relator(a) p/ Acórdão: Min. EROS GRAU, Tribunal Pleno, julgado em 07/06/2006, DJ 29-09-2006 PP-00031 EMENT VOL-0224902 PP-00142 RTJ VOL-00199-02 PP-00481. 
estabelecida entre correntista e banco enquadra-se como relação de consumo.

\subsection{Justificativas para o aprovisionamento de crédito}

Aconduta descrita adotada por alguns bancos fundamentase nas seguintes premissas conforme já se pôde observar em precedente jurisprudencial no qual se discutiu a questão da licitude dessa conduta: $1^{\text {a }}$ ) obediência à força obrigatória dos contratos (pacta sunt servanda), tendo em vista o consumidor, pessoa capaz, ter assinado livremente o contrato impresso autorizando o banco a debitar de seu saldo a quantia devida, não havendo se falar em ilegalidade; $2^{\mathrm{a}}$ ) o Supremo Tribunal Federal declarou a constitucionalidade do desconto de empréstimo consignado contratrado em contracheque de servidor público, à semelhança do que ocorre no caso do aprovisionamento de crédito de conta bancária do consumidor; $3^{\mathrm{a}}$ ) há perigo do inadimplemento antecipado do consumidor, ou seja, possibilidade de suas condutas demonstrarem de modo expresso ou implícito o seu desejo de não adimplir a obrigação contratada com o banco, o que equivaleria a sua mora e autorizaria, dessa forma, a antecipação da retenção da parcela devida.

Entretanto, parece-nos que essas justificativas apresentadas pelos bancos não se mostram aceitáveis, senão vejamos.

Realmente o princípio da força obrigatória dos contratos, também chamado de princípio da força vinculante dos contratos, princípio da intangibilidade dos contratos ou princípio da obrigatoriedade das convenções, indica que os contratos devem 
ser cumpridos, segundo Fiúza (2002), evidentemente, desde que realizados de acordo com a lei.

Conforme Marques (2002), referido princípio encontrase positivado no art. 1.134 do Código Civil francês, a indicar a obrigatoriedade dos ajustes entabulados livremente pelas partes, dos quais não se poderão desvincular, salvo em caso de outro ajuste ou pelas figuras da força maior e caso fortuito, não cabendo nem mesmo ao juiz modificar e adequar à equidade a vontade das partes manifestada no contrato.

Tartuce (2011) lembra que no Brasil não há norma legal prevendo esse princípio; assevera, ainda, que havia previsão no direito romano no qual o contrato não poderia ser revisto ou extinto, sob pena de ensejar insegurança jurídica ao sistema.

Entretanto, a sociedade evoluiu e observa-se nova dinâmica principiológica do Direito Contratual, apontada por Fiúza, especialmente a partir do início do século XX, quando se passou a observar a massificação dos contratos, decorrente da concentração industrial e comercial. O autor ainda destaca que atualmente a obrigatoriedade contratual fundamenta-se na Teoria Preceptiva, para a qual as obrigações decorrentes de contrato obrigam não apenas porque as partes as convencionaram, mas porque interessa à sociedade a tutela da situação objetivamente gerada, em face de suas consequências econômicas e sociais.

Em assim sendo, conforme bem observa Tartuce, não mais se admite na sociedade moderna a concepção estanque do contrato, ou seja, em que pese o princípio da força obrigatória de os contratos permanecerem no ordenamento jurídico brasileiro, já não se pode mais concebê-lo como regra absoluta e inafastável, como antes era entendido, assumindo a feição de exceção diante 
da função social do contrato, indicando que se encontra mitigado ou relativizado.

No âmbito do Superior Tribunal de Justiça, por exemplo, existem diversos precedentes jurisprudenciais ${ }^{7}$ nessa direção, estabelecendo a mitigação dessa força obrigatória dos contratos, em caso de relação de consumo, caso existam cláusulas abusivas em contrato, mormente em face do princípio da boa-fé objetiva ${ }^{8}$, da função social dos contratos ${ }^{9}$ e do dirigismo contratual ${ }^{10}$.

Implica reconhecer que o princípio da Força Obrigatória dos Contratos não pode mais ser encarado de forma absoluta e, caso a caso, poderá ser mitigado nas hipóteses descritas acima.

Portanto, como o contrato firmado entre consumidor e banco tem a natureza jurídica de contrato por adesão, no qual o consumidor não teve a oportunidade de discutir as suas cláusulas, cuida-se de relação de consumo. Por isso, havendo indícios da existência de cláusula abusiva, conforme será analisado abaixo, não pode prevalecer o aprovisionamento de crédito em conta bancária com base apenas no princípio da força obrigatória dos contratos, pois possível mitigar-se a sua aplicação.

A outra justificativa apresentada pelos bancos, no sentido de que o STF teria declarado a constitucionalidade do desconto

$7 \quad$ AgRg no Ag 1426031/SC, Rel. Ministro PAULO DE TARSO SANSEVERINO, TERCEIRA TURMA, julgado em 02/08/2012, DJe 07/08/2012. AgRg no Ag 1394166/SC, Rel. Ministro RAUL ARAÚJO, QUARTA TURMA, julgado em 08/05/2012, DJe 04/06/2012. AgRg no Ag 1379942/SC, Rel. Ministro PAULO DE TARSO SANSEVERINO, TERCEIRA TURMA, julgado em 06/03/2012, DJe 15/03/2012.

$8 \quad$ O Código Civil expressamente fez menção ao princípio: Art. 422. Os contratantes são obrigados a guardar, assim na conclusão do contrato, como em sua execução, os princípios de probidade e boa-fé.

9 O art. 421 do Código Civil estipula que: A liberdade de contratar será exercida em razão e nos limites da função social do contrato.

10 Fiúza (2002) define dirigismo contratual como a intervenção do Estado no domínio econômico que sempre ocorre em defesa dos bons costumes e da ordem pública. 
em folha de pagamento do empréstimo consignado contratado pelo consumidor, servidor público, não pode ser aceita, uma vez que se cuida de relação jurídica totalmente diferente daquela entabulada pelo consumidor, tratada neste trabalho, e que dá ensejo ao aprovisionamento de seus créditos em conta bancária.

O desconto da parcela do empréstimo consignado é realizado em folha de pagamento diretamente pelo órgão pagador do devedor, e existe convênio prévio firmado entre o banco e a instituição pública à qual se encontra vinculado o contratante, isto é, são duas situações jurídicas diferentes e inconfundíveis, razão pela qual a decisão do STF não enseja a consequência jurídica almejada pelo banco.

Em terceiro lugar, não pode ser aceita a tese do perigo do inadimplemento antecipado do correntista como justificativa para o aprovisionamento de crédito.

Assis (1997) ensina, invocando Pontes de Miranda, que o inadimplemento antecipado trata daquelas situações nas quais o devedor declara que não pode ou não quer adimplir a obrigação, havendo indisfarçável ameaça ao crédito, consubstanciada na declaração de não querer ou não poder cumprir com a obrigação contratada, mas, ao final, arremata com propriedade inexistir regra explícita em nosso ordenamento permitindo ao credor demandar a dívida antes do seu termo com base no inadimplemento antecipado.

Nesse ponto, convém asseverar que as instituições bancárias sujeitam-se aos riscos das atividades exploradas, possuidoras de condição de superioridade econômica gritante em relação a seus correntistas, novamente invalidando a tese de que o bloqueio das contas bancárias é justificado. 
Portanto, as justificativas comuns apresentadas para o bloqueio de crédito em conta bancária não podem ser aceitas.

\subsection{Natureza jurídica do aprovisionamento do crédito}

Antes de se adentrar na discussão sobre a natureza jurídica do ato de aprovisionamento de crédito em conta bancária, faz-se necessária uma análise dos atos prévios de constrição e de seus limites.

\section{A. Atos prévios de constrição e limites}

Com efeito, a ação executiva tem cunho eminentemente material, visto que se destina, em última análise, à satisfação de uma pretensão que já se encontra presente em um título executivo judicial ou extrajudicial, ou seja, persegue-se com esse tipo de ação a satisfação da pretensão do exequente descrita no título executivo, o que ocorre, no caso de obrigação de dar coisa certa, pela constrição do patrimônio do devedor e sua entrega ao credor.

Nesse contexto, entendem-se como atos prévios de constrição exatamente aqueles destinados a retirar da esfera do devedor, antes do ajuizamento da ação executiva, a parcela de seu patrimônio para a satisfação futura do crédito do credor, o que ocorre, normalmente, via ação cautelar preparatória, seja pelo 
arresto $^{11}$ ou pelo sequestro ${ }^{12}$, desde que atendidos os requisitos legais descritos no Código de Processo Civil.

Mais adiante será analisado que esse desapossamento prévio de bens do devedor, a par de sujeitar-se a requisitos específicos, reitere-se, em regra é privativo do Poder Judiciário, ou seja, normalmente não é permitida ao particular a expropriação de bens de seu devedor.

Ademais, esses atos de constrição, mesmo no curso do processo executivo, sujeitam-se a limites $^{13}$, que implicam o surgimento da previsão de bens absolutamente impenhoráveis e de bens relativamente impenhoráveis, ou seja, não é dado ao credor, mesmo pela atuação do Poder Judiciário, expropriar todos os bens do devedor quando presente alguma dessas situações excepcionais.

\title{
B. Conclusão parcial
}

Conforme analisado acima, a conduta do

\begin{abstract}
11 Art. 813 - O arresto tem lugar: I - quando o devedor sem domicílio certo intenta ausentar-se ou alienar os bens que possui, ou deixa de pagar a obrigação no prazo estipulado; II - quando o devedor, que tem domicílio: a) se ausenta ou tenta ausentar-se furtivamente; b) caindo em insolvência, aliena ou tenta alienar bens que possui; contrai ou tenta contrair dívidas extraordinárias; põe ou tenta pôr os seus bens em nome de terceiros; ou comete outro qualquer artifício fraudulento, a fim de frustrar a execução ou lesar credores; III - quando o devedor, que possui bens de raiz, intenta aliená-los, hipotecá-los ou dá-los em anticrese, sem ficar com algum ou alguns, livres e desembargados, equivalentes às dívidas; IV - nos demais casos expressos em lei.

12 Art. 822 - O juiz, a requerimento da parte, pode decretar o seqüestro: I - de bens móveis, semoventes ou imóveis, quando Ihes for disputada a propriedade ou a posse, havendo fundado receio de rixas ou danificações; II - dos frutos e rendimentos do imóvel reivindicando, se o réu, depois de condenado por sentença ainda sujeita a recurso, os dissipar; III - dos bens do casal, nas ações de separação judicial e de anulação de casamento, se o cônjuge os estiver dilapidando; IV - nos demais casos expressos em lei.

13 Nesse contexto, estipula o art. 648 do Código de Processo Civil: Não estão sujeitos à execução os bens que a lei considera impenhoráveis ou inalienáveis.
\end{abstract}


aprovisionamento de crédito em conta bancária de correntista destina-se à satisfação de débito contraído em contrato escrito firmado com o banco, porém, por costume, as instituições financeiras que adotam esse modelo simplesmente bloqueiam a quantia respectiva, retirando da esfera do patrimônio do devedor a possibilidade de administrar o montante. Tal ocorre porque o valor da parcela fica aprovisionado na conta bancária, entendase bloqueado para movimentação, e, posteriormente, debita-se normalmente a quantia da conta bancária.

Dessa forma, a nosso ver, o aprovisionamento em questão cuida-se de verdadeiro ato de constrição do patrimônio do correntista devedor, consubstanciando-se em bloqueio ${ }^{14}$ e inegável pagamento antecipado, e a questão que se coloca neste momento é se essa conduta do banco é lícita, resposta que depende inexoravelmente da análise de alguns aspectos relacionados à jurisdição.

\section{JURISDIÇÃO}

Em suma, entende-se que a jurisdição é o poder-dever do Estado-Juiz, legalmente investido, quando provocado, de aplicar o direito a determinado caso concreto, substituindo a vontade das partes pela vontade da norma, com o objetivo primordial de solucionar conflitos de interesses e com isso resguardar a ordem jurídica e a autoridade da lei.

14 Não se pode afirmar que se cuida de penhora da conta bancária do correntista, pois, conforme ensina José Lebre de Freitas, em sua obra A ação executiva depois da reforma da reforma, Coimbra Editora, $5^{\mathrm{a}}$ ed., a penhora é a apreensão judicial de bens do executado e como no caso ainda não existe ação executiva e o ato não é praticado por agente estatal, cuida-se de bloqueio e não de penhora. 
Dinamarco (2001) lembra que a jurisdição se cuida de monopólio estatal e inevitável e que dentre seus objetivos encontra-se o de dar efetividade ao ordenamento jurídico substancial.

\subsection{Vedação à autotutela no Direito Brasileiro}

Há muito se superou a possibilidade de utilização da autotutela para a resolução de lides no Brasil em face da superveniência da jurisdição como forma principal para resolução de conflitos. É bem verdade que, excepcionalmente, ainda se admite a autotutela, como, por exemplo, no caso da legítima defesa, do estado de necessidade e do desforço imediato nas ações possessórias, mas o fato é que não se admite o emprego da autotutela como regra para a resolução de conflitos ${ }^{15}$.

Cuida-se, em breve resumo, da resolução do conflito pelo emprego da força, ou seja, a prevalência do mais forte para estabelecer a prevalência de sua pretensão em detrimento da outra parte envolvida, razão pela qual não é preciso, nem é objeto deste trabalho, enfatizar as desvantagens do emprego da autotutela o que justifica, em parte, a sua superação nos dias de hoje.

A indagação que se coloca a esta altura é se o aprovisionamento de créditos em conta bancária do correntista pelo banco pode ser enquadrado como emprego da autotutela pela instituição financeira.

Comefeito, conforme consignado, a autotutela caracteriza-

15 Dinamarco (ob. cit. p. 120) classifica a autotutela como forma egoísta de autocomposição unilateral, antissocial e incivilizada, motivo pelo qual a lei proscreve e sanciona. 
se pelo emprego da força e pela manutenção da vontade do mais forte diante do mais fraco e, nesse ponto, não há dúvidas de que a conduta em estudo enquadra-se nessa possibilidade, tendo em vista que as instituições financeiras são verdadeiras potências econômicas se comparadas ao seu correntista, e o bloqueio, levado a efeito por elas, não se afasta em nada da satisfação de sua pretensão pelo emprego da força, ficando bem caracterizado o emprego da autotutela.

Ocorre, porém, que essa conduta, a par de não se enquadrar nas exceções que permitem a autotutela no ordenamento jurídico brasileiro, pode também violar outros princípios basilares do Estado Democrático de Direito, o que será objeto de análise a seguir.

\subsection{Princípios constitucionais}

A jurisdição se exerce por meio do processo, que é o método pelo qual se materializa a atividade jurisdicional.

Essa atuação do Estado-Juiz deve atender a determinados princípios descritos na Constituição Federal, destacando-se para este estudo, entre eles, os princípios da inafastabilidade da jurisdição, do devido processo legal e do contraditório e da ampla defesa.

\section{A. Inafastabilidade da Jurisdição}

Segundo o art. 5\%, XXXV, da Constituição Federal (CF/88), a lei não excluirá da apreciação do Poder Judiciário lesão ou ameaça de lesão a direito. Significa, em outras palavras, 
que, se a lei não pode afastar da apreciação do Poder Judiciário lesão ou ameaça de lesão ao particular, igualmente não é dada essa opção de afastar a atuação jurisdicional, o que certamente fundamenta e reforça a vedação da autotutela no Direito Brasileiro.

No caso em estudo, analisa-se se o correntista devedor tem o direito de ser processado pelo banco credor ou se é permitida a conduta de aprovisionamento de seu crédito depositado em conta bancária sem que isso viole o princípio descrito, ou, em outras palavras, indaga-se: o correntista tem o direito de não pagar o débito - entenda-se: não ter bloqueado crédito em sua conta bancária - fundamentando a sua conduta no princípio da inafastabilidade da jurisdição?

No caso em estudo, entende-se que ao credor é vedado bloquear crédito na conta bancária de seu correntista para fazer frente ao pagamento de débito contratado, pois essa conduta tem a natureza jurídica de bloqueio e de pagamento antecipado e é vedada a autotutela no Brasil, em regra, devendo a instituição financeira, para exercer o seu direito contratual, percorrer as mesmas vias jurisdicionais que qualquer outra pessoa jurídica ou física percorreria naturalmente em caso de inadimplemento contratual da outra parte.

\section{B. Devido processo legal}

$\mathrm{O}$ art. 5º LIV, da CF, de 1988, estabelece que ninguém será privado da liberdade ou de seus bens sem o devido processo legal.

O princípio do devido processo legal é o princípio base 
e como tal implica o direito de o cidadão ser processado ou processar de acordo com normas previamente estabelecidas (sentido formal) e, ainda, o direito a que as decisões judiciais sejam substancialmente devidas (sentido material).

Entretanto, é preciso enfatizar que o princípio do devido processo legal, além de dever ser respeitado tanto no âmbito legislativo, quanto no judicial e no administrativo, também deve ser atendido no âmbito das relações privadas, seja na fase pré-contratual seja na fase executiva, posto se tratar de direito fundamental previsto expressamente no texto constitucional.

Esse entendimento, segundo Didier Júnior (2008), também decorre da eficácia horizontal dos direitos fundamentais, ou seja, da possibilidade de aplicação do princípio do devido processo legal nas relações entre os particulares.

Na oportunidade, o doutrinador citou decisão do Supremo Tribunal Federal, proferida no RE $n^{\circ}$ 201.819/RJ, Relatora Ministra Ellen Gracie, relator para o acórdão Ministro Gilmar Mendes, na qual foi deferida a reintegração de um associado excluído da União Brasileira de Compositores (UBC), por violação do princípio do devido processo legal no procedimento administrativo que culminou em sua expulsão.

Nesse contexto, discute-se se há violação, ou não, do devido processo legal no contexto do aprovisionamento de crédito da conta bancária do correntista pelo banco.

Com efeito, depois do pronunciamento do STF acima citado, não há dúvida de que o princípio do devido processo legal deve ser respeitado mesmo nas relações entre os particulares.

Dessa forma, a conduta de o banco aprovisionar crédito parece transparecer uma grave violação ao princípio do devido 
processo legal, porque não se pode esquecer que, além de se encontrar descrito no Capítulo que cuida dos Direitos e Garantias Individuais e, portanto, proteger o consumidor, mesmo no âmbito privado, entende-se intuitivo que o aprovisionamento de crédito viola o devido processo legal em sentido formal.

\section{Contraditório e ampla defesa}

O princípio do contraditório e da ampla defesa encontrase descrito no inciso LV do art. $5^{\circ}$ da CF, de 1988, segundo o qual aos litigantes, em processo judicial ou administrativo, e aos acusados em geral são assegurados o contraditório e a ampla defesa, com os meios e recursos a ela inerentes.

O dispositivo é de clareza solar ao estabelecer que se aplica tanto a processos judiciais como administrativos, e a questão que se coloca neste instante é se o bloqueio de crédito na conta bancária do correntista violaria esse princípio.

Dinamarco (2001) ensina que contraditório significa participação e que participar do processo implica, para as partes, empregar as armas lícitas disponíveis com o objetivo de convencer o juiz a dar julgamento favorável ${ }^{16}$.

Em que pese fundar-se em relação negocial, e esse é um dos argumentos utilizados pelos bancos para justificarem o aprovisionamento, parece inegável a sua violação.

O que ocorre concretamente e todos os dias no Brasil é o bloqueio de crédito em conta bancária para adimplemento de parcelas de dívidas de consumidores levado a efeito por alguns 
bancos, à completa revelia dos titulares das contas bancárias, ou seja, bloqueia-se crédito em conta bancária para satisfação de obrigação, sem aviso prévio, sem notificação, sem explicação plausível, a não ser a celebração de um contrato por adesão.

Esse quadro não torna longe a conclusão no sentido de que a conduta do bloqueio pelo banco configura violação ao direito fundamental ao contraditório e à ampla defesa.

\section{Dignidade da pessoa humana}

A dignidade da pessoa humana encontra-se descrita como fundamento da República Federativa do Brasil no art. $1^{\circ}$, III, da CF, de 1988.

A questão que se põe neste instante diz respeito à violação desse postulado pelo aprovisionamento de crédito em conta bancária do consumidor por alguns bancos.

A dignidade humana é valor fundamental positivado no texto constitucional, mas se trata de um princípio importantíssimo na valoração de situações e atribuição de pesos em casos que envolvam ponderação.

A dignidade, nesse passo, é atributo de todo ser humano que, nesse contexto, merece o respeito independentemente de sua origem, raça, sexo, idade, estado civil ou condição social ou econômica, não podendo, portanto, ser limitada por circunstâncias externas.

Esse princípio, que se aplica tanto nas relações entre indivíduo e Estado como nas relações privadas, indica a necessidade de assegurar o mínimo existencial a todo cidadão, o que implica reconhecer, em regra, a sua precedência sobre 
outros interesses que com ele colidam.

Além disso, a dignidade da pessoa humana, em que pese encontrar-se como fundamento da República Federativa do Brasil, inegavelmente é parte do conteúdo dos direitos materialmente fundamentais, mas com eles não se confunde.

No caso concreto, entende-se que nas situações nas quais o aprovisionamento de crédito possa prejudicar de alguma maneira o mínimo existencial do correntista, estará clara a violação do princípio da dignidade humana, como seria o caso do bloqueio pelo banco da integralidade do salário do correntista depositado em conta bancária, inviabilizando a sua própria sobrevivência.

Destarte, mostra-se clara a proteção constitucional que a dignidade humana assegura aos cidadãos, dentre eles, o correntista de banco, e não se pode afastá-la, nessas hipóteses, em prol de proteção de um negócio jurídico entabulado entre as partes.

\section{ENFOQUE LEGAL}

\subsection{Vedação da penhora de vencimentos}

O art. 649, inciso IV, do Código de Processo Civil considera absolutamente impenhoráveis os vencimentos, subsídios, soldos, salários, remunerações, proventos de aposentadoria, pensões, pecúlios e montepios; as quantias recebidas por liberalidade de terceiro e destinadas ao sustento do devedor e sua família, os ganhos de trabalhador autônomo e os honorários de profissional liberal ${ }^{17}$. 
Nesse aspecto, discute-se se essa proteção poderia ser invocada pelo correntista da conta bancária que teve o seu provento, ou parte dele, aprovisionado pelo banco para pagamento de dívida.

De um lado, é bem verdade que essa norma aplica-se ao processo executivo, e no caso em estudo o contexto indica que ainda não teria havido ajuizamento de ação de execução em face do consumidor, motivo pelo qual, aparentemente, não haveria substrato para o devedor invocar essa proteção.

Por outro lado, porém, é preciso destacar que a finalidade primordial da instituição bancária com o aprovisionamento de créditos de seu correntista é exatamente fazer frente à dívida contraída e, nesse aspecto, conforme já consignado, cuida-se de bloqueio destinado a pagamento.

Nesse contexto, considerando-se que a penhora de bens, no curso da ação de execução, configura-se primordialmente como apreensão judicial de bens que se destina, posteriormente, à satisfação do crédito executado, não há dúvidas de que o fim do bloqueio realizado pelo banco e pela autoridade jurisdicional é o mesmo, ou seja, a satisfação futura do credor.

Além disso, entende-se que essa previsão do art. 649 do Código de Processo Civil configura-se primordialmente numa vedação expressa à atuação do órgão jurisdicional no âmbito da ação executiva, consubstanciando-se em verdadeira proteção do devedor e de sua família ${ }^{18}$.

competentiae (benefício de competência), isto é, a impenhorabilidade do estritamente necessário para a sobrevivência do executado e de sua família, e à sua dignidade e deve ser aplicado de ofício pelo magistrado.

18 Essa é a lição de Luiz Guilherme Marinoni e Daniel Mitidiero, in Código de Processo Civil, comentado artigo por artigo, Editora Revista dos Tribunais, 2008, pp. 639-640, para quem as impenhorabilidades são exigidas como uma densificação infraconstitucional da dignidade da 
Importa em reconhecer que o legislador limitou a atuação do Poder Judiciário em caso de ação executiva e, assim sendo, parece inconcebível admitir que um particular, ainda que titular de um direito expresso em contrato escrito, possa praticar conduta vedada ao Poder Judiciário, notoriamente em face da vedação da autotutela no Brasil.

Partindo dessas premissas, não há dúvida de que a conduta de o banco bloquear crédito em conta bancária de seu correntista, oriundo de provento, configura violação à impenhorabilidade prevista no art. 649, inciso IV, do Código de Processo Civil, mesmo não se tratando de ato praticado no curso de ação executiva.

\subsection{Da abusividade da cláusula que coloque o consumidor em desvantagem exagerada}

$\mathrm{O}$ art. 39, inciso V, do Código de Defesa do Consumidor estabelece claramente a proibição de o fornecedor exigir do consumidor vantagem manifestamente excessiva, e o seu art. 51, inciso IV, declara a nulidade da cláusula contratual relativa ao fornecimento de produtos e serviços que estabeleçam obrigações consideradas iníquas, abusivas, que coloquem o consumidor em desvantagem exagerada, ou seja, incompatíveis com a boa-fé ou a equidade.

$\mathrm{O}$ ponto que se discute neste instante diz respeito à possibilidade de considerar-se abusiva e, portanto, nula de pleno direito, a cláusula contratual que estabelece autorização ao banco para promover o débito automático de seus créditos na

pessoa humana (art. $1^{\circ}$, III, da CF/88). 
conta bancária de seu correntista, visto que, neste estudo, essa autorização é utilizada para justificar o aprovisionamento do crédito na conta bancária.

A questão é tormentosa, pois, em princípio, poderse-ia defender que não haveria vício na cláusula que autoriza o débito automático na conta bancária do correntista, mas as instituições financeiras que adotam o aprovisionamento vão além, excedendo-se na aplicação dessa cláusula, ao bloquear crédito na conta bancária do correntista ${ }^{19}$.

Marques (2002) assevera, quanto à abusividade de cláusulas contratuais, a possibilidade de se empregarem dois enfoques, um subjetivo e outro objetivo. Pelo primeiro, a abusividade aproxima-se do abuso do direito, previsto no art. 187 do Código Civil, indicando o desvio malicioso da finalidade social do contrato firmado. Já pelo enfoque objetivo, que seria a tendência atual em nosso sistema, a abusividade estaria relacionada aos novos paradigmas do contrato, como a boa-fé objetiva.

Dessa forma, entende-se que, como a cláusula que autoriza o débito automático tem sido deturpada ${ }^{20}$ por alguns bancos para justificar o aprovisionamento de crédito, mostra-se

19 Essa ampliação da noção da autorização do débito automático, a nosso ver, enquadra-se na definição de cláusula "surpresa" mencionada por Marques (2002), ou seja, aquelas que, segundo as circunstâncias, e, em particular, segundo a aparência global do contrato surpreendem o consumidor após a celebração do contrato.

20 Marques (2002) ainda assevera que "o arbítrio e a unilateralidade excessiva na fixação de elementos essenciais do contrato (sujeito, objeto, preço e consenso) detectados nas cláusulas leoninas e meramente potestativas são características comuns com as cláusulas hoje consideradas abusivas" e arrematada, citando Bricks, que "todas as cláusulas abusivas apresentam como características ou pontos em comum o seu fim, que seria melhorar a situação contratual daquele que redige o contrato ou detém posição preponderante, o fornecedor, transferindo riscos ao consumidor, e seu efeito, que é o desequilíbrio do contrato em razão da falta de reciprocidade e unilateralidade dos direitos assegurados ao fornecedor", indicando que esse desvio de finalidade por parte dos bancos enseja a abusividade da cláusula. 
desproporcional e viola a boa-fé objetiva, entregando ao banco verdadeira vantagem indevida, colocando o consumidor, em consequência, em desvantagem exagerada, sendo, portanto, nula de pleno direito nesses casos.

\subsection{Abuso do direito por parte do banco?}

$\mathrm{O}$ art.187 do Código Civil estabelece que também comete ato ilícito o titular de um direito que, ao exercê-lo, excede manifestamente os limites impostos pelo seu fim econômico ou social, pela boa-fé ou pelos bons costumes.

Cuida-se do que a doutrina convencionou chamar de abuso do direito que configura ato ilícito e se consubstancia, em última análise, no exercício anormal de um direito por seu titular.

$\mathrm{O}$ abuso do direito para que seja configurado depende da existência de alguns requisitos, qual seja, a existência de um direito protegido pelo ordenamento jurídico. E o seu titular, ao exercê-lo, exceda manifestamente os limites impostos por seu fim econômico ou social, pela boa-fé ou pelos bons costumes, e essa conduta seja manifesta.

A questão que se coloca nesse ponto remete à reflexão sobre a incidência desse postulado na conduta do banco que aprovisiona crédito da conta bancária de seu correntista para pagar dívida futura.

No caso em estudo, é inegável que o banco possui o direito de crédito em face de seu correntista, em virtude de taxas bancárias, empréstimos CDC ou faturas de cartão de crédito, mas o fato é que, ao efetuar o bloqueio de créditos na conta bancária, a instituição financeira excede-se no exercício de seu direito, 
ao arrepio da legislação, inclusive constitucional, configurando inegavelmente o abuso no exercício de seu direito ${ }^{21}$.

Relevante mencionar a hipótese de que, havendo dano ao consumidor, poderá haver a responsabilidade civil objetiva do banco, independentemente da demonstração de culpa por parte daquele que exerce o seu direito; basta que fique demonstrada a presença dos requisitos mencionados acima, ou seja, é irrelevante a discussão em torno da culpa no quadro do abuso de direito.

\section{ENFOQUE PRINCIPIOLÓGICO}

Neste momento, resta analisar a existência de violação a determinados princípios dirigidos à ação executiva no contexto da conduta do banco que bloqueia créditos na conta bancária de seu correntista para assegurar o pagamento de dívida.

A questão poderia ensejar alguma dúvida. Afinal, no caso em análise, não houve ajuizamento de ação executiva por parte do credor, o que, a nosso ver, não impede a incidência dos princípios abaixo descritos, porque independe da existência dessa ação quando a conduta do fornecedor enquadra-se claramente como ato prévio de constrição de bens do devedor, isto é, estar-se-ia perante uma situação de desapossamento e pagamento sem ação executiva que deve ser analisada, portanto, à luz dos dispositivos aplicáveis ao processo executivo porquanto semelhante a uma

21 Sérgio Cavalieri Filho (2007) cita precedente do Superior Tribunal de Justiça (REsp 250.523-SP, Rel. Min. Ruy Rosado de Aguiar) no qual reconheceu-se o abuso do direito de um banco que aprovisionou o saldo bancário de uma pessoa jurídica, por violação do princípio da boa-fé. No caso concreto, "o banco, para amortizar débito de uma empresa decorrente de contrato de mútuo, utilizou o saldo positivo que tinha ela em conta bancária. Por falta desses recursos, a empresa não pagou o salário de seus empregados que, por sua vez, fizeram greve, causando-lhe enormes prejuízos". 
fase pré-processual executiva.

\subsection{Princípio da menor onerosidade ao devedor}

O art. 620 do Código de Processo Civil estabelece que, quando por vários meios o credor puder promover a execução, o juiz mandará que se faça pelo modo menos gravoso para o devedor.

Consagrou-se, portanto, o princípio da menor onerosidade ao devedor, segundo o qual, havendo mais de uma opção para a satisfação do credor, deve-se adotar a menos onerosa ao devedor.

$\mathrm{O}$ ponto em discussão nesta fase refere-se à possibilidade de invocação desse princípio como fundamento para a vedação ao aprovisionamento dos créditos da conta bancária de correntista pelo banco.

A primeira reflexão que deve vir à tona nesse passo é a de que deve existir mais de um meio processual à disposição do credor para a satisfação do seu crédito, preservada, porém, a eficácia da prestação jurisdicional ${ }^{22}$, porque não se admite a concorrência entre técnicas processuais idôneas e inidôneas para a incidência desse dispositivo legal23 ${ }^{23}$.

No caso em estudo, a conduta do banco em aprovisionar créditos da conta bancária de seu correntista, conforme dito, configura-se em verdadeiro bloqueio e, posteriormente, em pagamento, razão pela qual se poderia alegar que o caminho é adequado, especialmente em face da ordem de preferência da

22 STJ, 3a Turma, REsp 801.262/SP, rel. Min. Humberto Gomes de Barros, j. em 06.04.2006, DJ 22.05.2006, p. 200.

23 Esse é o ensinamento de Luiz Guilherme Marinoni e Daniel Mitidiero, in Código de Processo Civil, comentado artigo por artigo, Editora Revista dos Tribunais, 2008, pp. 624-625. 
penhora, prevista no art. 655 do Código de Processo Civil ${ }^{24}$, que coloca o dinheiro em primeiro lugar na lista de bens.

Todavia, essa conclusão parece precipitada, pois, por outro lado, o correntista tem o direito ao contraditório e à ampla defesa, com os meios e recursos a ela inerentes, e, atualmente, em caso de execução de título executivo extrajudicial, como parece que seria o caso em análise, caso fosse ajuizada a ação executiva pelo banco, tem-se que a oposição dos embargos do devedor nem sequer dependeria de prévia garantia do juízo ${ }^{25}$, e os embargos poderiam ser recebidos pelo magistrado no efeito suspensivo $^{26}$, facultado ao executado oferecer à penhora outro bem que não os seus créditos em conta bancária, o que impediria a constrição prévia do dinheiro depositado.

Ademais, tanto a doutrina como a jurisprudência têm admitido no Brasil, atualmente, que a defesa do executado seja realizada por meio de exceção de pré-executividade, incidente processual por meio do qual o devedor pode discutir questões de ordem pública sem que haja necessidade de dilação probatória.

É sabido que, em regra, esse incidente não suspende o curso do processo executivo; entretanto, diante da possibilidade de discussão quanto à impossibilidade jurídica ou inexistência de título executivo, por exemplo, matérias de ordem pública, caso demonstrada de plano pelo devedor, nada impediria que o

24 Art. 655. A penhora observará, preferencialmente, a seguinte ordem: I - dinheiro, em espécie ou em depósito ou aplicação em instituição financeira.

25 Nesse sentido, estabelece o art. 736 do Código de Processo Civil: O executado, independentemente de penhora, depósito ou caução, poderá opor-se à execução por meio de embargos.

26 Adiante estabelece o art. 739-A, $\$ 1^{\circ}$ : O juiz poderá, a requerimento do embargante, atribuir efeito suspensivo aos embargos quando, sendo relevantes seus fundamentos, o prosseguimento da execução manifestamente possa causar ao executado grave dano de difícil ou incerta reparação, e desde que a execução já esteja garantida por penhora, depósito ou caução suficientes. 
magistrado suspendesse o curso do processo de execução.

Dessa forma, parece clara a existência de outro caminho ao banco credor que não o aprovisionamento dos créditos da conta bancária de seu correntista, razão pela qual essa conduta também viola o princípio descrito no art. 620 do CPC.

\subsection{Princípio da igualdade entre os credores}

\section{A. Breves considerações}

O princípio da isonomia encontra suporte no texto constitucional, nos termos do art. $5^{\circ}$, inciso I, da CF, de 1988, segundo o qual Todos são iguais perante a lei, sem distinção de qualquer natureza, garantindo-se aos brasileiros e aos estrangeiros residentes no País a inviolabilidade do direito à vida, à liberdade, à igualdade, à segurança e à propriedade.

Também encontra correspondência no art. $3^{\circ}$, inciso IV, da CF, de 1988, que estipula como objetivo fundamental da República Federal do Brasil promover o bem de todos, sem preconceitos de origem, raça, sexo, cor, idade e outras formas de discriminação.

Interpretando-se esses dispositivos constitucionais, implica reconhecer que, em regra, salvo as hipóteses legalmente previstas de privilégios creditórios ${ }^{27}$, os credores se encontram em situação de igualdade perante o Poder Judiciário na busca pela satisfação de seu crédito.

27 Essa situação justifica-se em face da fórmula geral tratar com igualdade os iguais $e$ desigualmente os desiguais, na medida das desigualdades até porque o art. 125, I, do Código de Processo Civil estabelece claramente dentre os deveres do magistrado o de preservar a igualdade entre as partes e neutralizar as desigualdades quando cabível. 
Aqui o cerne da questão gira em torno de saber se a conduta de o banco bloquear crédito em conta bancária de seu correntista violaria esse princípio.

É verdadeiro o brocardo que diz que o direito não socorre aos que dormem, ou seja, a satisfação da pretensão de uma pessoa está diretamente relacionada com sua atitude, notadamente de acionamento da tutela jurisdicional para esse fim.

Ainda se mostra lógica a conclusão no sentido de inexistir, em regra, litisconsórcio ativo necessário entre os credores de um devedor-consumidor, todavia, essas ideias não podem legitimar a conduta do banco credor que, prevalecendo-se de sua relação de superioridade em face de outros credores de seu correntista, simplesmente bloqueia os créditos de sua conta bancária para a satisfação de seu crédito.

Nesse contexto, é preciso considerar a hipótese de existirem outros credores desse correntista, inclusive de credores com direitos reais ou privilégios legais que o banco não possui e que seriam preteridos nessa ordem de preferência pela constrição prévia realizada pelo banco.

E mais, é possível que outros credores tenham ajuizado ação de execução em desfavor desse correntista, tendo frustrada a sua busca por bens do executado, o que poderia inegavelmente implicar verdadeira fraude à execução o ato de bloqueio levado a efeito pelo banco credor ${ }^{28}$.

Nessa hipótese, novamente parece concreta a violação

28 Hipoteticamente, ainda poderia ocorrer a situação de haver sido ajuizada ação de execução de alimentos em desfavor do correntista e de o banco credor aprovisionar o crédito em conta bancária impedindo a satisfação do crédito exequendo, o que violaria o disposto no art. $649, \$ 2^{\circ}$, do Código de Processo Civil segundo o qual o disposto no inciso IV do caput deste artigo não se aplica no caso de penhora para pagamento de prestação alimentícia. 
do princípio da isonomia entre os credores, a justificar a impossibilidade de aprovisionamento dos créditos do correntista pelo banco.

\section{B. Da ordem de preferências prevista no Código Civil}

O Código Civil estabelece as cláusulas que devem ser observadas quanto às preferências e privilégios créditos em seus artigos 955 a 965, e a questão que se coloca neste momento é se o ato de aprovisionamento de crédito em conta bancária violaria as disposições constantes da norma legal.

A discussão é relevante haja vista o art. 956 do Código Civil estabelecer claramente a possibilidade de haver discussão entre os credores quanto à preferência entre eles disputada ${ }^{29}$.

Nesse contexto, parece que a instituição bancária, no caso em estudo, deve ser qualificada como credora quirografária de seu correntista, posto não possuir preferência ${ }^{30}$ ao firmar o

29 Art. 956. A discussão entre os credores pode versar quer sobre a preferência entre eles disputada, quer sobre a nulidade, simulação, fraude ou falsidade das dívidas e contratos.

30 Art. 964. Têm privilégio especial: I - sobre a coisa arrecadada e liquidada, o credor de custas e despesas judiciais feitas com a arrecadação e liquidação; II - sobre a coisa salvada, o credor por despesas de salvamento; III - sobre a coisa beneficiada, o credor por benfeitorias necessárias ou úteis; IV - sobre os prédios rústicos ou urbanos, fábricas, oficinas, ou quaisquer outras construções, o credor de materiais, dinheiro, ou serviços para a sua edificação, reconstrução, ou melhoramento; V - sobre os frutos agrícolas, o credor por sementes, instrumentos e serviços à cultura, ou à colheita; VI - sobre as alfaias e utensílios de uso doméstico, nos prédios rústicos ou urbanos, o credor de aluguéis, quanto às prestações do ano corrente e do anterior; VII - sobre os exemplares da obra existente na massa do editor, o autor dela, ou seus legítimos representantes, pelo crédito fundado contra aquele no contrato da edição; VIII - sobre o produto da colheita, para a qual houver concorrido com o seu trabalho, e precipuamente a quaisquer outros créditos, ainda que reais, o trabalhador agrícola, quanto à dívida dos seus salários.

Art. 965. Goza de privilégio geral, na ordem seguinte, sobre os bens do devedor: I - o crédito por despesa de seu funeral, feito segundo a condição do morto e o costume do lugar; II - o crédito por custas judiciais, ou por despesas com a arrecadação e liquidação da massa; III - o crédito por despesas com o luto do cônjuge sobrevivo e dos filhos do devedor falecido, se foram moderadas; IV - o crédito por despesas com a doença de que faleceu o devedor, no semestre anterior à sua morte; V - o crédito pelos gastos necessários à mantença do devedor falecido e sua família, no 
contrato de abertura de conta bancária ${ }^{31}$.

Em assim sendo, em situação hipotética na qual o correntista possua outro credor, com crédito real ou crédito pessoal privilegiado ${ }^{32}$, havendo o aprovisionamento de crédito em sua conta bancária, entende-se que haveria, sim, violação às disposições constantes do Código Civil.

Diante da carência de decisões judiciais proferidas pelos Tribunais Brasileiros, destaca-se um precedente jurisprudencial do Tribunal de Justiça do Estado do Tocantins (TJTO) no qual um correntista teve o seu vencimento aprovisionado pelo banco para a satisfação de crédito consignado, e na ação ajuizada se pedia a condenação do réu ao pagamento de indenização por danos morais e desbloqueio da conta bancária.

Em primeiro grau, a juíza de direito julgou procedentes os pedidos formulados, limitando o aprovisionamento a $30 \%$ do valor depositado na conta bancária da parte-autora e condenou o banco-réu ao pagamento de indenização por danos morais.

Em grau de recurso, o TJTO manteve a sentença proferida em primeiro grau e acrescentou que a conduta do banco-apelante configurou-se como autotutela, ferindo o princípio da dignidade da pessoa humana.

trimestre anterior ao falecimento; VI - o crédito pelos impostos devidos à Fazenda Pública, no ano corrente e no anterior; VII - o crédito pelos salários dos empregados do serviço doméstico do devedor, nos seus derradeiros seis meses de vida; VIII - os demais créditos de privilégio geral.

31 Art. 958. Os títulos legais de preferência são os privilégios e os direitos reais.

32 Art. 961. O crédito real prefere ao pessoal de qualquer espécie; o crédito pessoal privilegiado, ao simples; e o privilégio especial, ao geral. 
O Exmo. Desembargador Relator asseverou o seguinte: "Não tenho motivos para duvidar da recorrida, e a lógica não me permite pensar de forma diversa, pois todos nós temos despesas mensais básicas. O aprisionamento da quase totalidade dos vencimentos da autora-recorrida, único meio de subsistência de sua família - que contempla esposo e dois filhos menores -, importa, por certo, na impossibilidade de suprir as suas necessidades mais básicas e dos seus, como moradia, alimentação e saúde".

Não consta recurso especial interposto ao Superior Tribunal de Justiça ${ }^{33}$.

\section{CONSIDERAÇÕES FINAIS}

Por todo o exposto, no caso em estudo, pode-se concluir que se aplica o Código de Defesa do Consumidor às relações jurídicas entabuladas entre o correntista e o banco, quando se enquadram com perfeição nas definições de consumidor e fornecedor previstas no Código de Defesa do Consumidor, e a jurisprudência consolidada no âmbito de nossos Tribunais Superiores, notadamente do STJ e do STF, caminha nessa mesma direção.

33 Eis a ementa do julgado: EMENTA: RECURSO DE APELAÇÃO. CONSIGNAÇÃO EM FOLHA DE PAGAMENTO. POSSIBILIDADE. LIMITAÇÃO AO PERCENTUAL DE 30\%, CONFORME ORIENTAÇÃO DO STJ. GARANTIA DO PRINCÍPIO DA DIGNIDADE DA PESSOA HUMANA. APROVISIONAMENTO DO SALÁRIO INTEGRAL DA CONSUMIDORA. DANOS MORAIS CONFIGURADOS. RECURSO IMPROVIDO. (APELAÇÃO CÍVEL No 5001318-23.2011.827.0000. ORIGEM: COMARCA DE GUARAÍ/TO. REFERENTE: AÇÃO DE RESTITUIÇÃO DE PROVENTOS RETIDOS COM PEDIDO DE TUTELA ANTECIPADA C/C INDENIZAÇÃO POR DANOS NN 2009.0006.8079-0. APELANTE: BANCO DO BRASIL S/A. ADVOGADOS: GUSTAVO AMATO PISSINI E SARAH GABRIELLE ALBUQUERQUE. APELADA: FRANCIELI NUNES DA SILVA VIEIRA. ADVOGADO: FÁBIO ARAÚJO ROCHA. RELATOR: Juiz HELVÉCIO DE BRITO MAIA NETO). 
Ainda que o aprisionamento de crédito na conta bancária do correntista tenha natureza jurídica de ato prévio de constrição de bens, os bancos não legitimam essa prática em virtude das justificativas: a) a força obrigatória dos contratos; b) a declaração de constitucionalidade do desconto em folha de pagamento pelo STF; e c) o risco de inadimplemento antecipado do correntista.

Também se conclui que a conduta de aprovisionamento de crédito em conta bancária configura indesejável emprego de autotutela por parte de alguns bancos, vedado pelo ordenamento jurídico e que ainda viola os seguintes princípios: a) inafastabilidade da jurisdição; b) devido processo legal; c) contraditório e ampla defesa; d) dignidade da pessoa humana; e) menor onerosidade ao devedor; f) igualdade entre os credores.

Por fim, esse bloqueio, levado a efeito por alguns bancos, pode caracterizar violação à vedação de penhora de vencimentos prevista no Código de Processo Civil, e abusividade, colocando o consumidor em desvantagem exagerada, além de configurar abuso do direito por parte do banco.

\section{REFERENCIAS}

ASSIS, Araken de. Manual do processo de execução. São Paulo: Editora Revista dos Tribunais, 1997.

BRASIL. Lei no 5.869, de 11 de janeiro de 1973. Institui o Código de Processo Civil. Brasília: Presidência da República Federativa do Brasil, 2013. Disponível em: $<$ http://www.planalto.gov.br/ ccivil_03/leis/L5869compilada.htm $>$. Acesso em 30 de janeiro 2013. 
- Constituição (1988). Brasília: Presidência da RepúblicaFederativadoBrasil,2013.Disponívelem: $<$ http://www. planalto.gov.br/ccivil_03/constituicao/constituicaocompilado. htm>. Acesso em 30 de janeiro 2013.

. Lei $\mathrm{n}^{\circ} 8.078$, de 11 de setembro de 1990. Dispõe sobre a proteção do consumidor e dá outras providências. Brasília: Presidência da República Federativa do Brasil, 2013. Disponível em: $<$ http://www.planalto.gov.br/ccivil_03/leis/ L8078compilado.htm $>$. Acesso em 30 de janeiro 2013.

. Lei $\mathrm{n}^{\mathrm{o}} 10.406$, de 10 de janeiro de 2002. Institui o Código Civil. Brasília: Presidência da República Federativa do Brasil, 2013. Disponível em:< http://www.planalto.gov.br/ ccivil_03/leis/2002/L10406compilada.htm>. Acesso em: 30 de janeiro 2013.

CAVALIERI FILHO, Sérgio. Programa de responsabilidade civil. São Paulo: Atlas, 2007.

DIDIER JÚNIOR. Fredie. Curso de direito processual civil: teoria geral do processo e processo de conhecimento. Salvador: Editora Podivm, 2008.

DINAMARCO, Cândido Rangel. Instituição de direito processual civil, vol. I. São Paulo: Malheiros Editora, 2001.

FIÚZA, César. Direito civil. Belo Horizonte: Del Rey, 2002. 
GRINOVER, Ada Pellegrini; VASCONCELOS E BENJAMIN, Antônio Herman de; FINK, Daniel Roberto; FILOMENO, José Geraldo Brito; WATANABE, Kazuo; NERY JÚNIOR, Nelson; DENARI, Zelmo. Código brasileiro de defesa do consumidor. São Paulo: Forense Universitária, 2001.

FREITAS, José Lebre de. A ação executiva depois da reforma da reforma. 5. ed. Coimbra: Coimbra Editora.

MARINONI, Luiz Guilherme; MITIDIERO, Daniel. Código de processo civil comentado artigo por artigo. São Paulo: Revista dos Tribunais, 2008.

MARQUES, Cláudia Lima; BENJAMIN, Antônio Herman V.; MIRAGEM, Bruno. Comentários ao código de defesa do consumidor. São Paulo: Revista dos Tribunais, 2006.

. Contratos no código de defesa do consumidor.

São Paulo: Revista dos Tribunais, 2002.

TARTUCE, Flávio. Manual de direito civil. São Paulo: Método, 2011.

Recebido em: 20/06/2014

Aprovado em: 06/08/2014 